\title{
Joanna Machut-Kowalczyk*
}

\section{PROBLEMY Z UJMOWANIEM DÓBR OSOBISTYCH NA TLE WOLNOŚCI SLOWA I OCHRONY CZCI W ŚWIETLE WYPOWIEDZI ZAMIESZCZANYCH NA LAMACH „GAZETY SĄDOWEJ WARSZAWSKIEJ”}

\section{Proces ksztaltowania koncepcji dóbr osobistych}

W XIX w. zaczyna się proces kształtowania koncepcji dóbr osobistych. Co prawda początkowo kodyfikacje cywilnoprawne wprowadzane na naszych ziemiach $^{1}$, nie definiowały dóbr osobistych ${ }^{2}$, a z europejskich jedynie kodeks szwajcarski posiadał ogólny przepis dotyczący bezprawnego wtracania się w stosunki osobiste ${ }^{3}$. Nie znajdujemy także takiej definicji w przepisach administracyjnych z XIX i początków XX wieku, ani w ustawodawstwie konstytucyjnym, choć szczegółowo wyliczano tam wolności i swobody obywatelskie (np. konstytucja z 17 marca 1921 r. przewidywała m.in.: ochronę życia, wolności ${ }^{4}$; wolności słowa, przekonań ${ }^{5}$, prasy $^{6}$ itd.).

* Dr, Katedra Historii Państwa i Prawa Polskiego, Wydział Prawa i Administracji Uniwersytetu Łódzkiego. Autorka publikacji jest stypendystką w ramach projektu „Kształcenie kadr dla potrzeb rynku flexicurity i gospodarki opartej na wiedzy - oferta kierunków nauk humanistyczno-społecznych UŁ”, współfinansowanego ze środków Unii Europejskiej w ramach Europejskiego Funduszu Społecznego.

1 Allgemeines Landrecht für die Preußischen Staaten (1794 r.), Code civile (1804 r.), Allgemeines Bürgerliches Gesetzbuch (1811 r.), Kodeks Cywilny Królestwa Polskiego (1825 r.) czy BGB (Bürgerliches Gesetzbuch, 1900 r.).

2 S. Grzybowski, Ochrona dóbr osobistych wedlug przepisów ogólnych prawa cywilnego, Warszawa 1957, s. 45.

3 Prawo cywilne, Część szczegółowa, skrypt wg wykładów prof. dr. E. Waśkowskiego, Wilno 1934 s. $5-6$.

${ }^{4}$ Pierwsze zdanie art. 95 Konstytucji z 17 marca 1921 r.: „Rzeczpospolita Polska zapewnia na swoim obszarze zupełną ochronę życia, wolności i mienia wszystkim bez różnicy pochodzenia, narodowości, języka, rasy lub religii”.

${ }^{5}$ Art. 104 Konstytucji z 17 marca 1921 r.: „Każdy ma prawo swobodnego wyrażania swoich myśli i przekonań, o ile przez to nie narusza przepisów prawa".

${ }^{6}$ Art. 105 Konstytucji z 17 marca 1921 r.: „Poręcza się wolność prasy. Nie może być wprowadzona cenzura ani system koncesyjny na wydawanie druków. Nie może być odjęty dziennikom 
Teoretycy zastanawiali się nad istnieniem jednego ogólnego prawa osobowości, czy też prawa ochrony poszczególnych dóbr osobistych (takich jak zdrowie, wolność, cześć, swoboda sumienia itp.). Przedstawiciele nauki prawa (zarówno w XIX, jak i XX wieku) byli zgodni, że ścisłej i wyczerpującej definicji tych dóbr nie da się sformułować. Przywołajmy w tym miejscu międzywojenny skrypt prawa cywilnego:

Wobec trudności wyliczenia wszystkich dóbr osobistych zaszła konieczność określenia wszechobejmującego prawa osobiste. Takie określenie nie jest jednak łatwe i w literaturze zjawił się ich cały szereg. Prof. Garcis, Niemiec, ojciec współczesnej teorii praw osobistych określił: że każdy ma prawo na uznanie swej indywidualności. Rohler - prawo osobistości to prawo żądać, by osoba moja była uznawana jako samoistna fizyczna i moralna jednostka. Gierke - że są to prawa, które nadają władztwo nad częściami własnej sfery osobistej. Ktoś inny powiedział, że prawo osobistości to prawo wyłączenia wszystkich od oddziaływania na sferę naturalną człowieka. Inny jeszcze, że prawa osobiste ochraniają dobra, nierozerwalnie związane z człowiekiem. Adler - że to są prawa, przeznaczone bezpośrednio i wyłącznie do ochrony osobistości, Zeiger /Austriak/ - prawa osobiste to prawa godności, nazwiska i swobody działalności każdej istoty. Puchta - że to jest zupełne władztwo nad losami własnej osoby. Małyszew - prawa osobiste to 1/ prawo nietykalności, 2/ prawo każdego do ochrony wyobrażenia współobywateli co do jego indywidualności. Określeń jest dużo i żadne nie jest całkowicie odpowiednie ${ }^{7}$.

W praktyce przepisy chroniące prawa osobiste wprowadzano stopniowo w różnych gałęziach prawa i w konsekwencji dobra osobiste chronione były nie tylko przez przepisy prawa cywilnego, ale także przez przepisy prawa administracyjnego ${ }^{8}$, karnego ${ }^{9}$, prawa pracy itp ${ }^{10}$. Dostrzegano to w to doktrynie:

i drukom krajowym debit pocztowy, ani ograniczone ich rozpowszechniania na obszarze Rzeczypospolitej. Ustawa osobna określi odpowiedzialność za nadużycie tej wolności”.

7 Prawo cywilne..., s. 4-5.

${ }^{8} \mathrm{~W}$ przepisach administracyjnych znajdujemy rozporządzenia mające chronić poszczególne dobra osobiste. Np. Komisja Rządowa Sprawiedliwości 8/20 grudnia 1852 r. wydała „Rozporządzenie, aby Sądy winnych nieludzkiego obchodzenia się z ujętemi przestępcami do odpowiedzialności pociągały”. W treści rozporządzenia przytoczono przykłady nieludzkiego traktowania więźniów. Np. „przestępca, bywa zaraz na miejscu przez przytrzymujących go nielitościwie bity, następnie skrępowany, częstokroć przez długą noc jesienną lub zimową a czasem i dłużej trzymany w zimnie i głodzie, nim go oddadzą do Wójta gminy lub Burmistrza, i w tym nawet transporcie nie raz dnie całe skrepowany leży na wozie, bo transportujący w każdej niemal karczmie zasilają się trunkiem, który, podniecając ich zapalczywość przeciwko związanemu przestępcy, daje powód do wywierania na nim nowych okrucieństw [...] odstawiony bywa do Sądu Policyi Poprawczej w stanie zupełnie chorobliwym, tak, że zaraz w szpitalu musi być umieszczony, gdzie częstokroć, obok najusilniejszego starania lekarza, życie kończy”, „Rozporządzenie, aby Sądy winnych nieludzkiego obchodzenia się z ujętemi przestępcami do odpowiedzialności pociągały" z 8/20 grudnia 1852 r., Zbiór Przepisów Administracyjnych Królestwa Polskiego, Wydział Sprawiedliwości, część II , Organizacja sadownictwa karnego, t. XI, 1867, s. 73-75).

9 Np. w art. 2 Kodeksu Kar Głównych i Poprawczych z 1847 r. czytamy: „Naruszenie przepisów wydanych dla zachowania ustawami zawarowanych praw, oraz powszechnego i osobistego bezpieczeństwa lub dobra, zowie się wykroczeniem".

10 S. Grzybowski, op. cit., s. 12-13. 
[...] obecnie powstały nowe kategorie stosunków i norm, których w prawie rzymskiem jeszcze nie było. Do nich należą prawa osobiste do czci, imienia, nazwiska, wolności, własnego wizerunku, tajemnicy korespondencji. Dobra te nie były dawniej pozbawione całkowicie ochrony prawnej, były bronione o tyle, o ile chodziło o wynagrodzenie krzywdy, nie stanowiły jednak samodzielnej kategorii praw, jak to ma miejsce dzisiaj. Następnie do liczby tych nowych kategoryj należy doliczyć prawo autorskie na utwory literackie, muzyczne, artystyczne, prawo o wynalazkach, prawo do firmy itd ${ }^{11}$.

Wskazano też cechy wspólne dla tych praw: ich bezwzględna skuteczność - erga omnes; ich niematerialny charakter. Dobra osobiste definiowane były jako przedmioty prawa osobistego ${ }^{12}$, a dla ochrony ich $\mathrm{w}$ okresie międzywojennym wyróżniano: „1). skargę o odszkodowanie, 2). o ustalenie, 3). o zaniechanie, 4). samopomoc i wreszcie 5). skargę w trybie postępowania karnego, o ile ustawa karna również broni zaczepionych dóbr"'13.

W II połowie XX w. jako cechę wspólną dóbr osobistych, wskazywano: „,niemajątkowe, indywidualne wartości świata uczuć, stanu życia psychicznego człowieka”"14 i proponowano wciąż daleką od doskonałości definicję: „Najogólniej mówiąc, dobrami osobistemi są takie dobra, które przedstawiają dla człowieka wartości niemajątkowe, psychiczne, jak np. dobra sława, cześć, nietykalność cielesna, wolność itp." 15

Atrakcyjnym źródłem informacji o kształtowaniu się koncepcji dóbr od ostatniej ćwierci XIX w., po wybuch II wojny światowej jest „Gazeta Sądowa Warszawska" ${ }^{\prime 16}$. Na jej forum pojawiło się, wiele artykułów o dobrach materialnych i niematerialnych i ich ochronie. W publikacjach poruszano zagadnienia ochrony dóbr osobistych osób fizycznych i prawnych ${ }^{17}$.

Najczęściej za dobra osobiste uważano pewne wartości niematerialne związane ściśle z człowiekiem (również z osobą prawną), ale niewiele jest artykułów

11 Prawo cywilne..., s. 3.

12 Ibidem, s. 3-4.

13 Ibidem, s. 8.

14 S. Grzybowski, op. cit., s. 78.

15 Ibidem, s. 9.

16 „Gazeta Sądowa Warszawska” jest bogatym źródłem informacji o prawie i jego stosowaniu w XIX i XX w. Wydawana była w latach 1873-1939, na jej łamach publikowano sprawozdania z głośnych procesów sądowych krajowych i zagranicznych, rozprawy naukowe (podzielone niejednokrotnie na odcinki), orzecznictwo karne i cywilne, listy do redakcji, dokonywano rozbioru pytan, itd. Więcej: S. Milewski, Gazeta Sąowa Warszawska, Historia czasopiśmiennictwa prawniczego, „Palestra” 2007, z. 1-2.

17 Na łamach „Gazety Sądowej Warszawskiej”, występuje też zagadnienie ochrony czci osób prawnych. W jednym z artykułów czytamy: „Osoba moralna, jako nie mogąca, ani posiadać, ani utracać honoru, nie może tem samem być podmiotem biernym przestępstw, zmierzających do jego nadwyrężenia. Lecz z drugiej strony państwo nie może być obojętnem na czyny, nacechowane pogardą dla instytucji rządowych, jako podkopujące powagę władzy krajowej”. O spotwarzeniu osób moralnych, „Gazeta Sądowa Warszawska” 1879, nr 20, s. 154. 
traktujących ogólnie o interesujących nas dobrach. Częściej natrafiamy na co ciekawsze kazusy z praktyki sądowej krajowej i zagranicznej. Sporo interesujących spraw dotyczyło m.in. ochrony miru domowego, swobody sumienia, prawa autorskiego. Wydaje się jednak, że za sztandarowe, bo najczęściej omawiane dobra należy uznać cześć (godność i dobre imię) i wolność słowa. W związku z tym na ich przykładzie postaramy się wskazać na pewne tendencje w kształtowaniu się opinii na temat dóbr osobistych, w wąskim środowisku prawniczym Kongresówki.

Nie da się oczywiście na podstawie tylko tego jednego źródła kompleksowo omówić tych dwóch dóbr osobistych. Wymagałoby to dokładnego przyjrzenia się praktyce sądowej w tym zakresie, a zwłaszcza szczególnie bogatemu zasobowi informacji, jakim są akta wydziałów policji prostej sądów pokoju, gdzie właśnie przeważają sprawy o obelgi słowne, czynne i potwarze ${ }^{18}$. Mnożenie się spraw o obelgi, potwarz widać też w statystykach i artykułach publikowanych na łamach „Gazety Sądowej Warszawskiej” [dalej: GSW] ${ }^{19}$.

\section{Cześć}

\section{Ochrona czci poddanego-obywatela}

Dużo uwagi publikujący na łamach GSW prawnicy poświęcali ochronie dobrego imienia i godności człowieka, przy okazji omawiania kazusów, w których opi-

18 Zob. np. Archiwum Państwowe w Łodzi, nr zespołu: 120, Sąd Policji Prostej Okręgu Zgierskiego: Akta Sądu Policyi Prostej pko. Ekart. Marya o obelgi, sygn. 3; Akta Sądu Policyi Prostej Okręgu Zgierskiego w sprawie pko: Augustowi Guze o obelgi i odgróżki, sygn. 29; Sprawa przeciwko Teofili Hejman o obelgi, sygn. 76; Sprawa przeciwko Elżbiecie Glesman i innym o rozpowszechnianie fałszywych informacji 1865-1867, sygn. 81; Sprawa przeciwko Teofili Jerzewicz o obrazę, sygn. 83; Akta Sądu Policyi Prostej Okręgu Zgierskiego w sprawie pko: Georgowi Fras o obelgi, sygn. 85; Sprawa przeciwko Janowi Benke i innym o oszczerstwo, sygn. 86; Sprawa przeciwko Fierlowi Drukier i innym o oszczerstwo, sygn. 97, k. 5; Sprawa przeciwko Moszkowi Wiązowskiemu o pobicie, znieważenie i oszczerstwa, sygn. 99.

19 Według opublikowanej na łamach GSW statystyki sądu gminy Blizne za rok 1871, spośród 75 osądzonych tam spraw policyjnych, 24 dotyczyły obelg, a 4 ubliżania członkom sądu gminnego na posiedzeniu. Ar. T., Sądownictwo Gminne, Z Sądu Gminy Blizne, statystyka z roku 1871, GSW 1873, nr 34, s. 271. W 1873 r. spraw o potwarze i obelgi było w całym Królestwie Polskim 1566. R. Buczyński, „Sprawozdanie sądowe za rok 1873”. Wydanie Kommissyi Rządowej Sprawiedliwości (po ros.), Literatura i Krytyka, GSW 1875, nr 29, s. 226.

W jednym z artykułów czytamy: „Ze wszystkich przestępstw najpospolitsze są obelgi (1), bo dotyczą tego rodzaju prawa osobistego, którego określenie in concreto jest najtrudniejsze, stąd też najłatwiej naruszeniu podlega. Trudność polega w szczególnie osobistym charakterze tego, co nazywamy czcią, tak że wartość jej prawie u każdego posiadającego jaźń, t. j. świadomość samego siebie, jest odmienna, nie co do istoty, ale co do formy". O jurysdykci w sprawach obelgowych, GSW 1881, nr 16, s. 127-129. 
sane zostały czyny wypełniające znamiona potwarzy ${ }^{20}$, obelg słownych i nie tylko. Ochrona tego dobra osobistego była uregulowana dość kazuistycznie na gruncie ówczesnego prawa karnego (np. Kodex Kar Głównych i Poprawczych, dział X, rozdział VI pt. $O$ obrazie honoru $)^{21}$. Regulacja prawna w zakresie czci budziła wiele wątpliwości ${ }^{22}$ i przysparzała wielu trudności w praktyce sądowej. Zmiany pojawiające się w tym zakresie niekiedy tylko komplikowały już i tak niejasną regulację. Najwięcej problemów występowało przy kwalifikacji prawnej. Nie łatwo było też sądom ocenić, czy w konkretnym przypadku doszło do naruszenia czci skarżącego. Nad znaczeniem pojęcia godności, czci, potwarzy, zastanawiano się na łamach GSW kilkakrotnie. W jednym z artykułów czytamy:

Skala pojęć o godności osobistej jest ogromnie szeroka, skala ta warunkuje się opinią publiczną i wykształceniem obrażonej jednostki, przechodzi od drażliwości, spowodowanej złym humorem, aż do szlachetnej zdolności przebaczania nawet ciężkiej zniewagi, - od zupełnego niemal braku poczucia osobistej godności, do pełnego jej zrozumienia. Sąd zatem karny, zastanawiający się nad tem, czy dany czyn jest obelgą lub nie: $1^{\circ}$ usiłuje rozwiązać zagadkę - nie do rozwiązania; $2^{\circ}$ orzekając, iż dany czyn nie był obelgą, staje na stanowisku sądu honorowego, lecz nie karzącego; ostatnie zaś jest jego zadaniem; $3^{\circ}$ wyrządza krzywdę obrażonemu. Czy dany czyn jest obelgą, czy nie - właściwym sędzią może być tylko obrażona osoba; skoro wnosi skargę, musi czuć się dotkniętą w swej osobistej godności ${ }^{23}$.

20 Np.: Sprawa o potwarze, GSW 1873, nr 33, s. 262; Potwarz, Wiadomości bieżące krajowe, GSW 1874, nr 37, s. 296; Potwarz, Wiadomości bieżące krajowe, GSW, nr 15, 1875, s. 114 [powinno być 120 , prawdopodobnie błąd w druku].

${ }^{21}$ Rozdział był podzielony na trzy oddziały:1. O przestępstwach przeciw czci i wstydowi niewieściemu (art. 1000-1009; 2. O bezpośrednich osobistych obelgach (art. 1010-1018); 3. O potwarzy i rozszerzaniu obelżywych lub innych sławie uwłaczających pism, obrazów i wizerunków, lub wieści (art. 1019-1026).

${ }^{22}$ W 1895 r. ukazał się artykuł poświęcony czci kobiecej. Autor we wstępie wymienił przestępstwa, które naruszały tę cześć według ówczesnego prawa. Pokazuje też różnorodność kwalifikowania takich czynów za granicą. Na łamach GSW czytamy: „W dziale przestępstw, ochrzczonych mianem »obraza honoru«, pierwsze miejsce w Kodeksie karnym obowiązującym zajmują przestępstwa »przeciwko czci i cnocie niewieściej«. Pozbawienie dziewictwa, zgwałcenie, porwanie i uwiedzenie - oto czyny, które prawo karne obowiązujące do kategoryi tych przestępstw zalicza. Z kodeksów cudzoziemskich jedne podciągają owe czyny pod rubrykę zamachów na wolność osobistą (np. szwedzki), inne znów zaliczają je do przestępstw »przeciwko dobrym obyczajom i spokojowi rodzinnemu«. (np. Kod. niemiecki, belgijski, włoski, hiszpański, portugalski). J.J. Litauer, Cześć niewieścia a władza rodzicielska, GSW1895, nr 21, s. 321.

${ }^{23}$ S. Czyń., Sprawa o obelgi, Kronika Kryminalna, GSW 1926, nr 20, s. 156-157. Parę lat później znów pojawia się problem odpowiedniego rozumienia pojęcia obelgi, potwarzy itd.: „krzywda honorowa wyrządzona dowodzenia nie potrzebuje, i aby wykazać, że skarżący istotnie ją poniósł, dość, aby świadkowie poświadczyli tożsamość jego z osobą, opisaną w zaskarżonym artykule, lub aby ta tożsamość z innych względów była widoczną. Inna rzecz z opinią. Tej skarżący mógł przez potwarz nie utracić, może publiczność wzgardziła paszkwilem i dla tego śledztwo ma za zadanie wykazać, czy pod tym względem istotnie jakie zło nastąpiło, lub też potwarz pozostała bezskuteczną. Opinia o człowieku może być rozmaitą w różnych kółkach towarzyskich, ale Sąd winien brać pod uwagę opinię najbliższych spotwarzonego osób, gdyż tylko ta przede wszystkiem go obchodzi”. W. Malagowski, Kilka uwag o potwarzy w druku, GSW 1876, nr 27, s. 215-218. 


\section{W innej publikacji z 1875 r. czytamy:}

[...] w znacznej liczbie wypadków sądy omijają prawne udowodnienie obelżywości czynu, i uznają go za taki na mocy jedynie wewnętrznego, a więc indywidualnego i chwiejnego własnego pojęcia o honorze i czci osobistéj. Tymczasem ocenienie, czy dany czyn jest obelgą i jaką mianowicie, przedstawia w każdej nieledwie sprawie dość ważne trudności, szczególniej téż pod powagą obecnie obowiązującego kodeksu, który odróżnia: obelgi słowne w piśmie lub druku, rozszerzanie potwarczych wieści przez pismo lub druk, obelgi czynne i lżejsze uszkodzenie na zdrowiu. Miejsce nie pozwala nam dokładniej kategoryzować rodzaju obelg, w kodeksie przewidzianych; chodziło nam tylko o wskazanie głównych, zasadniczych kategoryj, a już samo ich zestawienie przekonywa, że pojęcia te, tak ściśle się ze sobą zlewają, iż czynią niepodobném zakreślenie między niemi stałej, niewzruszonemi pojęciami prawnemi obwarowanéj granicy. Na najpierwszém miejscu postawić tu nam wypada trudność ocenienia, czy zaskarżone wyrażenie się słowne jest obelgą, czy nie? ${ }^{24}$.

Poza komentowaniem przepisów prawa, prawnicy zastanawiali się również nad stosunkiem obrażonego do naruszenia jego dobra osobistego. $\mathrm{Z}$ przedstawionych w GSW rozważań wynika, że cześć, honor, godność przedstawiała dla Polaków ogromną wartość. Jeden z autorów przytoczył myśl pochodzącą jeszcze z XVI w.:

„Skoro ty jedno polakowi czcią zagrozisz (mówi St. Orzechowski w XVI wieku), już go wiedź kędy chcesz, rozkaż mu co chcesz, wypuść go na co chcesz; albowiem to, co u innych ludzi szkoda, łańcuch, kłoda, śmierć, to u polaków cześć wszystko waży i daleko więcej nad to wszystko". Zmienił się stan polityczny, zmieniły i stosunki społeczne, jednakże pojęcia te, które wyrobiły się przy dawnym porządku rzeczy, nie zmieniły się do takiego stopnia, żeby je mierzyć było można miarą jakiegoś ogólnie-przecięciowego Europejczyka²5.

Natrafiamy niekiedy na łamach omawianego periodyku jedynie na krótkie wzmianki w dziale wiadomości bieżących krajowych, kpiące z wrażliwości niektórych poddanych. Na przykład Andrzej Synowiec posługujący przy kościele parafialnym w Zadrożu został oskarżony o obelgi, których dopuścił się na szkodę Maryanny G. Okoliczności były następujące. Pokrzywdzona podczas uroczystości kościelnych chciała wraz z innymi kobietami nieść obraz. Przeszkodził jej w tym pan Synowiec szarpiąc ją za ramię. Obwiniony tłumaczył się w sposób następujący:

Maryanna G. odznaczająca się od wielu rówieśniczek swoich - dziewcząt - gorszącém prowadzeniem, zasługiwała na większą ze strony pasterza parafii baczność, upoważniającą go do zastosowania przeciwko jej sposobowi życia energicznych i skutecznych represyj. Moral-

W $1881 \mathrm{r}$. ten temat poruszył inny autor: „Ale oprócz powodów czysto osobistych, obraza czci ma jeszcze dwie podstawy: społeczną, ze stosunku osobnika, do otaczającego koła tak właściwie społecznego, narodowego, plemiennego, wyznaniowego, albo klassy społecznej, stanu, professyi i t. p. jakoteż tej sfery towarzyskiej, z którą przestaje i której reguły przyjął lub też przyjać jest obowiązany”. O jurysdykcji w sprawach obelgowych, GSW 1881, nr 16, s. 127-129.

${ }^{24} \mathrm{Z}$ przedstawionego później przez autora przykładu wynika, że sąd wymierzył winnemu potwarzy słownej karę jednego miesiąca i piętnastu dni w domu poprawy K., Sprawa o obelgi słowne, Kronika Kryminalna, GSW 1926, nr 1, s. 6-7.

${ }^{25}$ O jurysdykci w sprawach obelgowych, GSW 1881, nr 17, s. 135-136. 
nym, a nadającym się ku temu środkiem było zabronienie jéj noszenia, na równi z cnotliwémi dziewczętami, obrazów, czego skutkiem być miało obrażenie miłości własnéj Maryanny $\mathrm{G}^{26}$.

\section{Ochrona czci organów państwa}

Często poruszanym zagadnieniem w GSW była ochrona czci państwa i urzędników ${ }^{27}$. W jednym $\mathrm{z}$ takich artykułów (opublikowanym w 1877 r.) próbowano przybliżyć powody, dla których to przewinienie jest spenalizowane:

Państwo, w dzisiejszem jego pojęciu, otoczone jest majestatem, nie ulegającym żadnej krytyce, tym bardziej zniewadze. Takiż sam majestat otacza jedną ze składowych części państwa, Władzę Najwyższą, z ramienia której powstają organa państwowe, urzędnicy rządowi. Urzędnicy ci nie mają własnego majestatu państwowego. Cześć ta stanowi cześć urzędniczą, która nadaje urzędnikowi prawo do poszanowania, nie uwalnia go jednak od odpowiedzialności przed państwem, w imię którego działa. Odpowiedzialność tę mogą wywołać nawet osoby prywatne, skoro prawa ich obrażone zostały. W osobach prywatnych jednoczy się więc z jednej strony obowiązek uszanowania czci urzędniczej, z drugiej strony prawo krytyki i skargi na działalność urzędnika. Ztąd, gdy zajdzie potrzeba wykonywania tego ostatniego prawa, dla prywatnej osoby rodzi się trudne położenie, wobec którego potrzeba wiele roztropności, aby umieć bronić swoich praw, a mimo to nie obrażać. Następstwem trudności tych są nieskończone zajścia, któremi zajęte są sądy nie tylko nasze, lecz i wszystkich krajów ${ }^{28}$.

Z drugiej strony można zaobserwować zaniepokojenie społeczeństwa możliwością naruszania przez urzędników swoich uprawnień ${ }^{29}$. O sprawie w przedmiocie takiego nadużycia wyrokował między innymi Sąd Okręgowy Odeski. Obwinionym o nadużycie w urzędowaniu był Sędzia Pokoju Miasta Olgopola. Okoliczności były następujące:

${ }^{26}$ Obelgi. Wiadomości bieżące krajowe, GSW 1876, nr 32, s. 261. Podobnie: Zniesławienie. Wiadomości bieżące krajowe, GSW 1876, nr 37, s. 302.

27 Np.: J.B., Sprawa o zniewagę urzędnika, Kronika Kryminalna, GSW 1874, nr 2, s. 13-14; Proces pułkownika Stoffela o zniewage urzędnika, Kronika Zagraniczna, GSW 1874, nr 3, s. 23, 30; Zniewaga urzędnika, Wiadomości bieżące krajowe, GSW 1874, nr 37, s. 295; X.X., Sprawa Bergmana, obwinionego o znieważenie władzy, Kronika Kryminalna, GSW1874, s. 93; Obelgi czynne podczas odbywania czynności urzędowych, Wiadomości bieżące krajowe, GSW 1874, nr 43, s. 344, Znieważenie urzędnika, Kronika Kryminalna, GSW 1877, nr 16, s. 127; Zniewaga urzędnika, Wiadomości bieżące krajowe, GSW 1877, nr 45, s. 361; Al. K., Sprawa Adwokata, obwinionego o zobelżenie Toważysza Prezesa Sąu Okręgowego, Kronika Kryminalna, GSW 1879, nr 45, s. 364-365; $Z$ departamentu kryminalnego,. Wyrok w sprawie Kazimierza Budrewicza o zobelżenie urzędnika, Jurisprudencya Senatu, GSW 1892, nr 1, s. 8-9 itd.

28 Znieważenie urzędnika, Kronika Kryminalna, GSW 1877, nr 16, s. 127.

${ }^{29}$ „W maju 1876 r. we wsi Modliszewice oficer Ł. dopuścił się nadużycia władzy, za co w wyniku głośnego procesu został skazany przez sąd na trzy miesiące aresztu. W opisującym ów proces artykule czytamy: Następnie zabrał głos prokurator Martinów, a streściwszy w krótkiem omówieniu przebieg zajścia, wnioskował, że podsądny L., nie tylko nadużył dozwolonej mu władzy, siłą swych żołnierzy wymierzając sobie sprawiedliwość, ale nadto przestąpił prawo, w sposób ubliżający traktując słownie równego mu stanowiskiem człowieka, wnosił więc za ukaraniem winnego 6-cio miesięczném aresztem na odwachu". Nadużycie władzy, Wiadomości bieżące krajowe, GSW 1877, nr 6, s. 48. 
Służący Sokołowa doniósł mu, że kucharka p. Dmitriewskiego, u którego się sędzia stołował, powiedziała, ,że Dmitriewski żywi Sokołowa z łaski”. Sędzia obraził się temi zaocznie wyrzeczonemi wyrazami i spisał protokuł treści następującej: „Mnie, Sędziego pokoju Olgopolskiego, obraziła włościanka Anna Dunajenkowa, i narobiła mi wiele przykrości, i dla tego stanowię, aby pociągnąć ją do odpowiedzialności sądowej. W imieniu Najjaśniejszego Pana, na zasadzie art. 119 Ustawy o karach, wymierzanych przez sędziów pokoju, skazuję włościankę Annę Dunajenkową na zamknięcie w areszcie policyjnym przez miesiąc jeden”. Następnie sędzia dodał klauzulę egzekucyjną i kazał wykonać ten wyrok. Obrońca podsądnego starał się go obronić niewiadomością prawa. Przysięgli uniewinnili podsądnego ${ }^{30}$.

W nr 19 z 1875 r. pojawia się informacja o procesie Ludwika Gajzlera, redaktora odpowiedzialnego „Kuryera Poznańskiego” o obrazę ministerstwa i o obrazę ks. kanonika Dulińskiego, w zamieszczonych w kurierze korespondencjach z Gniezna. Wydział Karny Sądu Powiatowego Poznańskiego skazał obwinionego na 2 miesiące więzienia za pierwsze przewinienie, a za drugie wymierzył mu karę grzywny w wymiarze 50 tal. (z możliwością zamiany na dwa tygodnie więzienia) $)^{31}$.

Wrażliwość sądów na różnorakie pomówienia była przedmiotem kilku publikacji. W jednej (z 1878 r.) opisano sprawę Kazimierza Waszczuka, który w I instancji został skazany za nieuszanowanie sądu gminnego ${ }^{32}$. Sprzeczne zeznania ${ }^{33}$

${ }^{30}$ Nadużycie w urzędowaniu, Wiadomości bieżące krajowe, GSW 1875, nr 6, s. 48.

31 Sprawa prasowa, Wiadomości bieżące zagraniczne, GSW 1875, nr 19, s. 152.

GSW donosiła również o przypadkach, w których zniewaga sądu była poważna. „W Czerniowcach na posiedzeniu sądu karnego doszło do następującego zdarzenia: Dora Ensler, dowiedziawszy się, iż wyrzeczenie przysięgłych wypadło niekorzystnie - poczęła gwałtownie krzyczeć i wpadłszy w istny szał miotała obelgi na trybunał. Drugi podsądny, Bayer, zachęcony przykładem Enslerowej, zwrócił się do sędziów przysięgłych i znieważył ich całym stekiem słów obrażających, jak „Gesindel” (hołota) i t.p. Przykład zniewagi znalazł naśladowców wśród licznej publiczności izraelickiej, która przysłuchiwała się rozprawie. Ozwało się sykanie, następnie świst, krzyki i cały tłum publiki, wyłamawszy galeryę, przeznaczoną dla słuchaczów, wpadł do miejsca, gdzie stoją ławy przysięgłych i trybunału sądu. Przewodniczący trybunału, otoczony zewsząd wzburzonym tłumem, uciekł się do dzwonka, ale ani dzwonka ani nawoływań nie było słychać. Dozorca więzień, Kulik, pragnął uspokoić tłuszczę, awanturnicy jednak porwali go między siebie i obili, porozrywawszy na nim odzież w kawałki. Sytuacya stała się tak groźną, że trybunał i przysięgli, nie czekając dalszych następstw, salwowali się ucieczką do dalszych pokoi, zamknąwszy drzwi od sali obrad, gdzie pozostali tylko podsądni i czerń rozjuszona”. Zniewaga Sądu, Kronika Zagraniczna, GSW 1885, nr 11, s. 171.

32 „Okoliczności faktyczne według znieważonego Sądu Gminnego przedstawiały się następująco: pozwolił sobie mówić, do Sądu, nie wstając z miejsca, rozparłszy się na ławce, w półsiedzącej postawie, a następnie, kiedy sędzia gminny kazał spisać protokół o odmówieniu przez Waszczuka wykonania przysięgi, ten, machając rękami i chodząc wzdłuż i wszerz po sali posiedzeń, zaczął podniesionym głosem ganić czynności Sądu, mówiąc, że Sąd nałożył zbyt małą karę pieniężną na winnego i że w składzie Sądu niewłaściwie bierze udział osoba, znajdująca się w stosunkach pokrewieństwa z jedną ze stron, spór wiodących. Prócz tego, kiedy sędzia gminny rozkazał sporządzić protokół co do nieprzyzwoitego zachowania się Waszczuka w sądzie i żądał następnie od niego, żeby podpisał protokół, Waszczuk, niepodpisawszy go, samowolnie oddalił się z sali posiedzeń".

33 „Jeden ze świadków zeznał: Waszczuk w Sądzie zachowywał się przyzwoicie, że z sędzią rozmawiał stojący, nie machając rękami i nie rozpierał się w ławce z poręczami, gdyż w sądzie nie 
i zarzut Kazimierza Waszczuka o udział w składzie tegoż sądu brata jednej ze stron, przeciwko której wtedy zeznawał, doprowadziły do uchylenia przez Izbę Sądowa Warszawską wyroku Sądu Okręgowego Siedleckiego i uznania Waszczuka niewinnym zarzuconego mu czynu ${ }^{34}$.

W nr 20 z 1879 r. zaś pojawił się artykuł opisujący proces sądowy o potwarz na sąd gminny. Ławnik sądu gminnego w Żelewie, przedstawił sędziemu tegoż sądu skargę na komisarza do spraw włościańskich Stachowicza, który będąc u niego w gościnie pomówił cały skład sądu gminnego (określił, że w jego skład wchodzą „łapownicy”). Reakcja była natychmiastowa - cały skład sadu gminnego domagał się ukarania komisarza. Sprawę rozpoznał Sąd Okręgowy Piotrkowski. Komisarz Stachowicz został uniewinniony. Wśród motywów czytamy:

1. że w wyrażeniu się S. „wyroki tendencyjne”, użytem w rozmowie prywatnej, nie można dopatrzeć się cech niezbędnych dla przestępstwa potwarzy; 2. że zeznanie świadka Kobylańskiego, ze względu na art. 716, 717 ust. post. krym., nie może być przedmiotem poważnego rozbioru, gdyż nieoznaczenie czasu jako też i osób, rozmawiających o działalności sądu gminnego - pozbawia sąd możności dojścia do źródła rozpowszechniania o sądzie gminnym wieści; 3. że ani w Ustawie o karach ani w Kod. Kar nie przewidziano wypadku, w którym by osoba fizyczna podlegała karze za obrazę osoby moralnej - gdy fakt ogranicza się na odmawianiu tejże osobie pewnych moralnych przymiotów i nie obraża wyraźnie i bezpośrednio jej przedstawicieli; 4. że wskutek tego w czynie kom. S. nie ma cech ani potwarzy, ani też jakiegokolwiek bądź innego występku ${ }^{35}$.

\section{Wolność słowa w konkurencji do ochrony czci}

Wśród artykułów dotyczących ochrony dóbr jest sporo poświęconych wolności słowa. Niektóre z nich starają się pokazać absurdalne ingerencje władzy, ośmieszając organy stojące na straży tzw. cenzury ${ }^{36}$. Inne pokazują interesującą

ma nawet poręczy u ławek. Drugi: że protokół nie był spisany zaraz, aż dopiero w trzy dni, kiedy bowiem pisarz Sądu zapytywał sędziego jakże będzie z protokółem, to sędzia tylko machnął ręką i do badania świadków w sprawie, do której się zebrali, nie przystąpiono".

${ }^{34}$ W. Sadk, Sprawa Kazimierza Waszczuka, obwinionego o jawne nieuszanowanie dla Sadu, Kronika Kryminalna, GSW 1878, nr 44, s. 350-351.

35 A.E., Sprawa o potwarz na sad gminny, Kronika Kryminalna, GSW 1879, nr 20, s. 157.

${ }^{36}$ W 1873 r. ukazał się np. artykuł opisujący sprawę czasopisma „Kolce”. W jednym z numerów nie zamieszczono wzmianki o zezwoleniu cenzury i o drukarni. Warszawski Komitet Cenzury wystąpił do Prokuratora Królewskiego przy Sądzie Kryminalnym w Warszawie z żądaniem pociągnięcia do odpowiedzialności sądowej redaktora i właściciela drukarni. Redaktor tłumacząc się w sądzie zauważył, że zakwestionowany numer miał zezwolenie cenzury na druk, a opuszczenie tej wzmianki miało miejsce tylko w niektórych egzemplarzach i prawdopodobnie było skutkiem omyłki drukarza. Sprawa została osądzona przez Sąd Kryminalny w Warszawie. Redaktor został uwolniony od zarzutu naruszenia cenzury. W artykule czytamy: „redaktora odpowiedzialnego nie może ciążyć dopełnienie formalności czysto drukarskich”. J.R., Sprawa o wykroczenie przeciwko przepisom cenzuralnym, GSW 1873, nr 10, s. 77. Podobnie: Wiadomości bieżące i rozmaitości, Przekroczenie cenzuralne, GSW 1873, nr 33, s. 263; nr 38, s. 304. 
dyskusję dotyczącą z jednej strony ograniczenia wolności słowa właśnie, a z drugiej strony ochrony czci ${ }^{37}$.

Wolność słowa niekiedy ograniczana była faktycznie poprzez zastraszanie redaktorów, a co za tym idzie opinii publicznej. Taka sytuacja miała mieć miejsce we Włoszech, o czym pisano w GSW nr 18 z 1875 r. ${ }^{38}$

Inny charakter miała odpowiedzialność redaktora za naruszenie praw osób trzecich na łamach redagowanej publikacji. Gdzie zaczyna się odpowiedzialność redaktora? $\mathrm{Na}$ to pytanie próbowano znaleźć odpowiedź na łamach omawianego czasopisma. W jednym z artykułów czytamy:

[...] redaktor winien użyć wszelkich środków, jakie leżą w jego mocy, dla przekonania się czy komunikowane mu wieści są prawdziwe w przeciwnym razie ulega karze za rozprzestrzenianie potwarzy, które miało miejsce właśnie wskutek jego nieostrożności i lekkomyślnego pełnienia obowiązków. Rozumie się, mówi Senat, że zdarzają się wypadki, gdy redaktor czasopisma otrzymującego zewsząd wiadomości, szybkie komunikowanie których dla czytelników jest, z uwagi na charakter wydawnictwa, koniecznem, znajdzie się w niemożności sprawdzenia czy wiadomości są rzeczywiste i polegając na dobrej wierze korespondentów, znanych redakcyi, może zostać przy zbiegu szczególnych okoliczności wprowadzonym w błąd, w takim wypadku odpowiedzialność za potwarz powinna spaść wyłącznie na współpracownika lub korespondenta. Uwolnienie redaktora od odpowiedzialności karnej w takich wypadkach, oparte na rozpatrzeniu treści wyjaśnień jego i ocenie stosunku jego do osobistości współpracownika lub korespondenta, położenia społecznego tego ostatniego i źródeł, z jakich wiadomość czerpano, będzie w zupełności zgodne z celami wymiaru sprawiedliwości ${ }^{39}$.

Autor innego artykułu skrytykował wprowadzoną zmianę w zakresie karania m.in. potwarzy w druku. Chodziło o odebranie możliwości osobom prywatnym dochodzenia nieprawdziwości opublikowanych informacji. W artykule czytamy:

Sąd ma za zadanie ocenić, czy odnosi się to do skarżącego i czy stanowi rzeczywiście obelgę lub potwarz, po stwierdzeniu się zaś téj okoliczności ma wymierzyć karę, nie powinien zaś

37 „W d. 25 października (6 listopada) 1879 r. przed Sądem Okręgowym Radomskim, sądzona była sprawa o potwarz w druku. Sąd skazał panów C.S. i R.S. za potwarz (art. 1535 kod. kar.) na karę po dwa tygodnie aresztu i polecił opublikować wyrok na ich koszt”. Sprawa prassowa, Kronika Kryminalna, GSW 1880, nr 3, s. 23-24.

38 „Redaktorowie we Włoszech nie długo znikną zupełnie, bo jednych nieprzyjazne pomordują stronnictwa, a drudzy przerażeni losem towarzyszy, poświęcą się innemu zawodowi, który na śmierć nie naraża. Jeszcze nie wyjaśniła się sprawa zamordowania p. Sanzogno, redaktora dziennika „Capitale”, a już nowa o podobnéj zbrodni dochodzi wiadomość. P. Henryka Hind, właściciela dziennika neapolitańskiego „Osservatore”, znaleziono nieżywego w studni własnego domu. Zrazu sądzono, że to samobójstwo, bliższe atoli badania udowodniły dostatecznie, że to było morderstwo, dokonane z pobudek politycznych". (Redaktorowie we Włoszech, Wiadomości bieżące zagraniczne, GSW 1875, nr 18, s. 144).

39 Odpowiedzialność redaktora czasopisma, Kronika z Cesarstwa, GSW 1887, nr 41, s. 269. Temat odpowiedzialności redaktora poruszany był również w innych publikacjach. Np.: Sprawa p. Nikotadze, redaktora gazety..., obwinionego o naruszenie praw prasowych, Kronika z Cesarstwa, GSW 1879, nr 31-34, s. 251; 258-259; 266-267; 274-276. 
i nie może wdawać się w rozbiór przedstawianej exceptio veritatis. W razie jedynie potwarzy, odnośnie do służbowej działalności osób, może tylko przyjąć dowód piśmienny ${ }^{40}$.

Autor tej publikacji wyraził sprzeciw zamieszczaniu obelg i potwarzy w druku. Zdawał sobie sprawę z ratio legis wprowadzonych zmian ${ }^{41}$. Z drugiej jednak strony obawiał się zamknięcia drogi spotwarzonym przedsiębiorcom przez „tzw. reklamy" do odzyskiwania dobrego imienia ${ }^{42}$.

W 1885 r. w GSW pojawiło się doniesienie z zagranicy o przestępczej działalności jednego redaktora. Ów „redaktor” dorabiał sobie na szantażu groźbą naruszenia prywatności. Sąd kryminalny wymierzył mu karę 13 miesięcy więzienia ${ }^{43}$.

W GSW nawiązano raz do sprawy o potwarz w druku z powodu krytyki literackiej. Mianowicie w nr. 35 „Prawdy” z 1885 r. ukazał się artykuł pod tytułem Sztandar ze spódnicy. Publikacja ta w sposób krytyczny odnosiła się do zbioru

40 B., O obelgach i potwarzy w druku, GSW 1875, nr 14, s. 106-107.

${ }^{41}$ „Żadna obelga, żadna potwarz choćby publicznie rzucona, nie rozejdzie się tak daleko, nie zaszkodzi moralnie tyle, co rozpowszechniona przez druk; bo gdy pierwsza obejmie pewną miejscowość, gdzie może nawet przebrzmieć bez wrażenia, gdy osobistość, którą spotwarzyć chciano, jest wyższą nad zarzuty, druga - dojdzie do odległych miejsc, tam nawet gdzie nie znają bliżej osoby, i gdzie w skutek tego imie jéj na wiarę drukowanego słowa oczernioném zostanie. Druk otwiera obszerne pole dla zawiści, paszkwilu i osobistych niechęci, należy więc stawić im przeszkodę, a w razie, gdy bez względu na karę wystąpią jawnie, nie dozwolić daléj się rozszerzać przez zbieranie dowodów w śledztwie sądowém”. Ibidem.

42 Autor podał następujący przykład: „W jedném z pism perjodycznych przed dwoma blisko laty pojawił się obszerny artykuł, w którym autor, rozwodząc się najprzód nad znaczeniem higieny, zacząwszy rzecz tę od greków, doszedł do opisu, że w pewnym ogrodzie jest mleczarnia, gdzie trują ludzi jakąś miksturą, podawaną na brudnych naczyniach, że jest to zbrodnia przeciwko zdrowiu publicznemu i t. p . Na drugi dzień w témże piśmie wyraźnie wydrukowano, że artykuł wspomniany nie odnosi się do mleczarni pana A., ponieważ zaś w tym ogrodzie były tylko dwie mleczarnie, zatém odnosić się musiał do drugiej należącej do pana N. Artykuły te są widoczną reklamą dla pana A., opartą na naganie produktów pana N. i są potwarzą, gdyż bezwątpienia zaszkodziły jego dobremu imieniowi, podkopały jego renomę i odstręczyły mu gości. Autor artykułu żadnych nie miał dowodów na poparcie swego twierdzenia, swoje zatém osobiste, może błędne zdanie, rzucał jako zdanie ogółu, i na swojém pojęciu o dobroci mleka uczynił niepowetowaną materyalną i moralną dla przedsiębiercy krzywdę. Artykuł 12 wspomnianego prawa nakazuje ukarać go, gdyż nie wolno mu prawdziwości takiego zarzutu dowodzić". Ibidem.

43 „Odwiedzał gorliwie sądy policyi poprawczej, notując nazwiska i adres osądzonych, wybierając tych, którzy, podług jego wyrażenia, dobrą mieli minę, a przyszedłszy do domu do tych ostatnich wystosowywał list następującej treści: »Panie (albo pani)! Trybunał skazał cię za czyn ciężko cię kompromitujący. W charakterze redaktora „Petit Journal des Tribunaux”, pisma bardzo rozpowszechnionego, muszę zdać sprawę z tego procesu. Zastać mnie można codzień rano od godziny 10 do 11, w biurze, gdzie udzielam posłuchanie za nim się artykuł ukaże w dzienniku«. Można sobie wystawić sensacyę osoby, która taki odebrała liścik. Węglarz, który oszukiwał na wadze, kupiec lub przekupień, którzy fałszowali wino lub mleko, widzieli nieodwołalnie straconą swoją reputacyę. Nie ma rady, mówili sobie, niech co chce kosztuje, trzeba zapobiedz rozgłoszeniu tej nieszczęsnej sprawy; czemprędzej więc spieszyli do Marsa". (Redaktor przed sądem kryminalnym, Wiadomości bieżące, GSW 1885, nr 11, s. 173-174). 
utworów p. Snieżko-Zapolskiej, zatytułowanego Akwarelle. Autorka wystąpiła ze skargą przeciwko redaktorowi Świętochowskiemu i autorowi Popławskiemu. Sąd okręgowy postanowił skargę pani Śnieżko-Zapolskiej, jako niezasadną oddalić ${ }^{44}$.

Pochodzący z 1929 r. artykuł poświęcony był wyrokowi w związku z krytyką pracy naukowej (zarzut obrazy czci). Wśród jego motywów czytamy, że zarzut wskazywał niewłaściwą formę krytyki naukowej. Autor (Władysław Wolter) jednak sceptycznie nastawiony do wyroku przytacza ,katalog inkryminowanych zwrotów":

[...] fantazja, fantastyczna przesada, curiosum natury fizjologicznej, zarzucanie autorowi płytkości i lekkomyślności w interpretowaniu prawdy, zarzucanie twierdzeń mijających się z prawdą, sprzecznych z codzienną obserwacją, zarzucanie wprowadzania chaosu i pomieszania pojęć. Twierdzi również krytyk, że książka roi się od błędów, nie spełnia minimalnych warunków podręcznika szkolnego, wreszcie pozwala sobie mówić o wyjaśnieniach i thumaczeniach autora, przyczem słowa wyjaśnienia i tłumaczenia stawia w cudzysłowach ${ }^{45}$.

Zdaniem autora $\mathrm{w}$ tym konkretnym przypadku mamy do czynienia $\mathrm{z}$ dozwoloną krytyką pracy naukowej.

O wolności słowa, prasy w GSW pisano też chętnie na przykładzie głośnych procesów o ochronę czci organów państwa. W 1885 r. ukazał się np. artykuł poświęcony procesowi o obrazę czci cesarza Wilhelma i kanclerza Bismarcka ${ }^{46}$. Ob-

${ }^{44}$ Adw. Pilecki, uzasadniając oskarżenie, dowodził, że artykuł „Sztandar ze spódnicy” przekracza granice przyzwojtej krytyki. Autor jego zwraca się często z zjadliwemi konceptami wprost do osoby autorki, zowiąc ją »osobą romansową, której rozkiełznana wyobraźnia" « itd. dalej krytyk twierdzi, iż wszystkie zbyt jaskrawe obrazy miłosne w „akwarellach” są reminiscencyami przeżytych przez autorkę uczuć i zdarzeń. Tym sposobem krytyk wdziera się w życie prywatne autorki i półsłówkami usiłuje splamić jej cześć. Najjaskrawszem jednak nadużyciem czysto kryminalnej natury jest postawiony przez krytykę zarzut, jakoby „Małaszka” byla przeróbką z drukowanej w Charkowie powieści rossyjskiej, a nowelka „Gdybyś ożyła” przeróbką z francuzkiego (Mademoiselle Galathée), i do tego tak oryginału blizką, że nudny formalista nazwałby ją wprost plagiatem. $\mathrm{Na}$ poparcie jednak takiego twierdzenia krytyk żadnego dowodu przedstawić nie jest w stanie. Że spotwarzenie p. Śnieżko dokonanem zostało przez krytykę rozmyślnie i ze złą wiarą, dowodem tego, obok fałszywości zarzutu plagiatu, jest ton całego artykułu i owa zjadliwość, z którą krytyk do osobistości autorki się zwraca”. W.C., Sprawa o dyffamacyę i potwarz z powodu krytyki w „Prawdzie”, Kronika Kryminalna, GSW, nr 17, 1886, s. 269-270.

45 W. Wolter, Krytyka naukowa i obraza czci, GSW 1929, nr 14, s. 207-211.

46 O częstym procesowaniu się Bismarcka donosiła GSW już dziesięć lat wcześniej: „Ks. Bismarck należy do ludzi najwięcej mających procesów. Wątpić można, aby ktokolwiek z żyjących mógł się z nim równać w tym względzie. Do d. 1 listopada r. z., książę posłał do rozmaitych sądów 784 skargi, i to wyłącznie przeciwko redaktorom dzienników, rządowi nieprzychylnych. W skutek tych skarg zapadło 610 wyroków, skazujących redaktorów w ogólnéj summie na 39 lat i 9 miesięcy więz”. (K. Bismark, Wiadomości bieżące krajowe, GSW 1875, nr 1, s. 8).

Kilka lat później ponownie skomentowano jeden z wytoczonych przez Bismarcka procesów: „Jeden z dzienników niemieckich Został pociągnięty do odpowiedzialności za ostrą krytykę polityki kanclerza. Prokurator żądał wymierzenia surowej kary. Tymczasem wydział karny sądu ziemiańskiego w Strasburgu uwolnił redaktora od wszelkiej odpowiedzialności, podając motywa, że chociażby 
winiony - filozof, który ponoć w opublikowanej przez siebie broszurze obraził obu pokrzywdzonych, bronił się w sposób następujący:

[...] cesarza niemieckiego nie można obwiniać o żaden z czynów ks. Bismarka, a co się tyczy tego ostatniego, opisywał i krytykował (ten filozof) tylko wypadki, które rzeczywiście się wydarzyły, i są powszechnie znane [...] mówiąc o morderstwie myślał o wznieconej przez ks. Bismarka wojnie, że zabijanie we wojnie nazywają niektórzy filozofowie morderstwem ${ }^{47}$.

W dwudziestoleciu międzywojennym materia ochrony czci organów państwa i ograniczeń z tym związanych nadal budziła dużo emocji. W 1926 r. z krytyką spotkało się rozporządzenie z mocą ustawy wydane przez Prezydenta Rzeczypospolitej z 4 listopada 1926 r. o karach za zniewagę władz i ich przedstawicieli. Wolność prasy zagwarantowana przez art. 105 Konstytucji RP została, zdaniem autora w znacznej mierze zawieszona przez ten akt prawny. W artykule komentującym tę zmianę czytamy:

\begin{abstract}
I wówczas gdy w myśl 74 art. konstytucji w imieniu Rzeczypospolitej Polskiej sprawiedliwość wymierzają sądy, art. 7 promulgowanego w n-rze 110 Dziennika Ustaw rozporządzenia powołuje do orzekania o przestępstwach, przewidzianych w tem rozporządzeniu, władze administracyjne drugiej instancji lub szczególnie przez ministra spraw wewnętrznych upoważnione władze administracyjne pierwszej instancji ${ }^{48}$.
\end{abstract}

\title{
Podsumowanie
}

Dyskusja na temat ochrony dóbr osobistych na łamach GSW nie jest tak różnorodna, jak tego można by oczekiwać biorąc chociażby pod uwagę dyskusje teoretyków prawa w omawianym okresie. Autorzy sygnalizują trudności występujące w praktyce przy ocenie, czy w konkretnym przypadku mogło dojść do naruszenia dóbr osobistych. Wskazują na niełatwe pogodzenie praw obywatela (do $1918 \mathrm{r}$. - poddanego) do krytyki urzędnika, z ochroną jego czci i godności.

Pod koniec XIX w. dyskusja na temat wolności słowa i ochrony czci była dużo bardziej ożywiona niż na początku XX w. Autorzy publikacji komentują w przeważającej większości głośne procesy sądowe, niekiedy pozwalając sobie na krytykę wprowadzanych przez państwo uregulowań prawnych. Charakterystyka publikacji poświęconych dobrom osobistym jest różnorodna. Widać wyraźnie,

\footnotetext{
nawet można w wywodach rzeczonego artykułu dostrzec jakąś obrazę, uwzględnić należy, iż jest obowiązkiem i najgłówniejszym zadaniem prasy peryodycznej poddać pod dyskusję wszelkie zajścia i wypadki życia politycznego. Zaprzeczenie tego zadania wyrównywałoby zawieszeniu i zniesieniu wolności prasy". (Proces o obrazę Bismarcka, Wiadomości bieżące, GSW 1884, nr 40, s. 646).

${ }^{47}$ S. Tokarski, Proces o obraze czci cesarza Wilhelma, i kanclerz ks. Bismarka, Kronika Zagraniczna, GSW1885, nr 37, s. 586-589.

${ }^{48}$ H. Karnecki, Zagrożenie wolności prasy, GSW 1926, nr 46, s. 627-628.
} 
że prawnicy szukali atrakcyjnych przypadków, nie ograniczając się jedynie do kazusów krajowych. Wzmianki o procesach zagranicznych pojawiają się na łamach GSW, niekiedy bez głębszej analizy. Biorąc pod uwagę całokształt omówionych publikacji, widać wyraźnie, że pojęcia dóbr osobistych dopiero się kształtują. Nie dotyczy to jedynie czci i wolności słowa, ale również innych dóbr osobistych. Na przykład w nieomówionych tu artykułach, prawnicy zastanawiali się jak zakwalifikować obcięcie kobiecie bujnych loków przez zazdrosną koleżankę ${ }^{49}$. Prawnicy dostrzegali problem niedookreślenia przez prawodawcę niektórych pojęć i braku przepisów ogólnych - kompleksowo zabezpieczających ochronę dóbr osobistych. Widać to chociażby w opisanym na łamach GSW przypadku sprzedaży żony przez męża. Sądy miały wątpliwości, jak zakwalifikować taką transakcję. Doszło do przekroczenia uprawnień mężowskich? Czy może naruszenia godności człowieka? A może do pozbawienia wolności ${ }^{50}$ ? Prawo nie tyle nie nadążało za zmieniającymi się stosunkami społecznymi, a raczej nie było $\mathrm{w}$ stanie przewidzieć wszystkich możliwych do wystąpienia życiowych sytuacji.

${ }^{49} \mathrm{~Np}$. w Wiadomościach bieżących zagranicznych opisana została sprawa o obcięcie loków przez zazdrosną koleżankę. Na łamach GSW czytamy: „Były na balu, tańczyły tuż obok siebie. W wirze walca panna D. słyszy te słowa: „Ach, te cudne, cudne loki”. Słowa te wyrzekł porucznik. „Wojna z lokami”- zawołała w duchu panna D., i w dwa dni po balu zaprosiła do siebie przyjaciółkę na herbatę. Rozmawiają, bawią się; panna R. siada do fortepianu; z pod palców jéj wypływa smętna sonata Beethovena - panna D. słucha, zbliża się, staje za grającą, i śród najsilniejszego „forte” odcina loki przyjaciółce. Panna R. nie czuła wcale téj operacyi, dopiero w domu u siebie przy toalecie spostrzegła amputacyę. Pobiegła do przyjaciółki z wymówkami, lecz ojciec panny D. obrażony, skarży ją o oszczerstwo; wówczas pani R. staje w obronie córki i skarży o uszkodzenie ciała. Sędziowie byli w ambarasie, gdyż nie ma dotąd w kodeksie paragrafu, specyalnie o lokach traktującego, jednak na wniosek prokuratora połatano paragrafy, i sąd skazał zdobywczynię loków na 5 dni więzienia, albo 15 talarów kary" (Proces o loki, Wiadomości bieżące zagraniczne, GSW 1875, nr 27, s. 216).

${ }^{50}$ W „Kronice Kryminalnej” w 1873 r. zamieszczony został artykuł poświęcony głośnemu procesowi, w wyniku którego ostatecznie Sąd Kryminalny w Warszawie skazał dwóch mężczyzn Jana Sz. (sprzedającego swoją żonę) za „nadużycie praw małżeńskich” i Karola B. (kupującego cudzą żonę) ,za uczestniczenie w tym przestępstwie" na karę osadzenia w wieży na 4 miesiące i dwa dni, pokutę kościelną i koszty procesu. Jak ustalono w śledztwie okoliczności faktyczne były następujące: „Jan Sz. po obrachowaniu pieniędzy danych mu przez karczmarza, kopnął żonę nogą i popchnął ją za kratę, gdzie stał karczmarz B. Ten zaś wziął ją za kołnierz, że się tak wyrażę, i zaprowadził do alkierza. Nikt z obecnych pomimo płaczu żony Jana Sz. nie przyszedł jéj z pomocą; opór więc w tym wypadku ograniczyć się musiał, tylko do płaczu i oburzenia, widocznego ze słów: przecież nie jestem zwierzęciem, abym miała być sprzedawaną... skutkiem postępku obwinionych, było ścieśnienie wolności żony Jana Sz., trwające od wieczora do południa dnia następnego". J. Radw., Sprawa o sprzedaż żony, Kronika Kryminalna, GSW 1873, nr 12, s. 91-95. 